\title{
Experience of regime regulation of distance learning in conditions of the spread of new coronavirus infection (COVID-19)
}

\author{
Yulia Isakova $^{1,{ }^{*}}$ and Marina Alekseeva ${ }^{1,2}$ \\ ${ }^{1}$ Don State Technical University, Rostov-on-don, Russia \\ ${ }^{2}$ Russian customs academy, Rostov-on-don, Russia
}

\begin{abstract}
The organization of the educational process in the second half of the 2019/2020 academic year in the condition of the declared coronavirus pandemic has become a difficult test not only for pupils, students and their parents, but also for the entire educational system of the Russian Federation. The regulation of this issue was formed in real time, and the rules were subject to immediate application to ensure not only the continuation of training, but also to ensure the epidemiological welfare of citizens. That is why the authors attempted to analyze in-depth the legal aspect of regulating the organization of distance education in the conditions of the spread of a new coronavirus infection.
\end{abstract}

\section{Introduction}

The Federal Law of 29.12.2012 No. 273-FL "On Education in the Russian Federation" [1] (hereinafter - the Federal Law on Education) defines the legal basis for the use of elearning and distance education technologies in the implementation of educational programs.

At the same time, there are many problems and difficulties in the practice of using elearning and distance learning technologies, and taking into account this fact, the question of the need to rethink the concept of providing educational services based on the development of distance learning has been repeatedly raised by scientists and teachers [2].

In 2019/2020, the coronavirus pandemic provided a powerful impetus for the development of distance learning. In particular, ensuring compliance with the anti-epidemic regime in educational institutions, their complete or partial closure, turned out to be associated with an emergency transfer of students to distance learning.

Experts believe that this situation can be considered as a natural experiment in the intensive introduction of distance learning technologies in education and it is now important to carefully document the actions taken by the educational organization in pandemic conditions and their consequences in order to further analyze their applicability in the education system [3].

Within this framework, the experience of the regime regulation of distance learning is of particular importance, including taking into account the fact that a high-alert or emergency

\footnotetext{
* Corresponding author: isakova.pravo@bk.ru
} 
regime has not been introduced throughout the Russian Federation or in part due to the threat of the spread of a new coronavirus infection (COVID-19).

In particular, first of all, it should be noted that ensuring compliance with the antiepidemic regime in educational organizations revealed significant gaps in the legislation in terms of establishing urgent measures for the implementation of educational programs and conducting state final certification in the event of a threat and (or) the occurrence of individual emergencies, and Federal law No. 164-FL of 08.06.2020, which amended this part of the Federal law on education (paragraph 17 of article 108), these measures determined the use of e-learning and distance educational technologies [4].

\section{Materials and methods}

The study of this issue was based on a formal and logical method, comparison and analysis for the possibility of comparing not only the current regulatory legal acts and their individual parts, but also the implementation of such regulations in practice on the example of educational institutions in Russia.

\section{Results}

Before entry into force of Federal law No. 164-FL a basis of realization of law-enforcement function on ensuring transition to distance learning the fixed concrete regime rule "provide observance of the anti-epidemic mode in the educational organizations, whenever possible to provide transition to distance learning" and Ministry of Education's acts of Russia and Ministry of Education and Science of the Russian Federation which are putting into operation it provided the resolution of the Chief state health officer of Russia of 13.03 .2020 No. 6 "About additional measures for reduction of risk of spread of COVID-2019" [5].

At the same time letters (of 13.03.2020 No.CK-150/03, of 17.03.2020 No.DT-41/06, etc.) were primary acts of this regime regulation of the Ministry of Education of Russia. Ordered regime regulation for transition to distance learning in the conditions of ensuring compliance with the anti-epidemic mode in the educational organizations of Ministry of Education of Russia began to carry out a later (orders of 17.03.2020 No. 103 and No. 104, of 19.03.2020 No. 106, of 25.03.2020 No. 125, etc.). The Ministry of Education and Science of the Russian Federation ordered regime regulation of distance learning in these conditions provided initially (orders of 14.03.2020 No. 397 and 398, of 19.03.2020 No. 450, of 25.03.2020 to No. 484 , etc.).

In the message of the Government of the Russian Federation dated 19.03.2020 "On measures to protect public health from a new coronavirus infection", it was noted that the subjects of the Russian Federation were instructed to "ensure compliance with the antiepidemic regime in educational organizations, including, if necessary, switching to distance learning and work. The Ministry of education of the Russian Federation has created a working group that will develop a unified procedure for organizing and supporting distance education" [6].

Taking it into account, it should be noted that within ensuring compliance with the antiepidemic mode in the educational organizations use of remote educational technologies and electronic training is considered by one of tools of the organization of training. Despite this, in the spring of 2020 practically all educational organizations were administratively transferred to distance learning.

However, this transition was not quite successful. It was not easy to build a training system and implement the curriculum in a remote format. An education system, with a large 
number of people: about 1.5 million school teachers and teachers of higher education institutions and also 16 million pupils and 7 million students, was "on the first front line" [7].

So, according to the research conducted by Analytical center NAFI at the end of March, 2020 , two thirds of Russian school teachers $(68 \%)$ expressed the opinion that "the system of school education isn't ready to switch to distance learning". It revealed "the lack of necessary equipment for many students, bad quality of Internet connection or total absence of Internet access". Were mentioned the availability and free of charge the general education and secondary professional education guaranteed by the law, for a solution the all-Russian action "Help to Study at Home" [8], broadcasting on OTR and "Tricolor" of educational TV channel "My School online" were urgently started. Despite this, due to various reasons, not all parents supported the school's transition to distance learning. Obviously distance education can be compulsory only when a high-alert, emergency situation or state of emergency is imposed. In other cases it is entered only on a voluntary basis.

At the level of higher education, the problems were slightly less. Following the methodological recommendations of the Russian Ministry of education and science, universities have developed scenarios for implementing distance learning and requirements for the educational process formats that are acceptable for their level of IT infrastructure development, taking into account available external resources.

The most popular among universities were LMS platforms for posting content and checking students' knowledge, webinar services for online lectures and consultations, social networks and messengers for communication between students and teachers, and email newsletters for content delivery.

Many higher education institutions could use free online courses from the leading Russian and foreign universities placed on national (NPOO) and international (Coursera, etc.) platforms. To help teachers of higher education institutions organize distance learning the Volunteers of Education project was started.

However, even these opportunities couldn't provide development by students of online courses because free access to content of courses didn't assume support of students from higher education institutions of holders of online courses, and teachers from the universities consumers weren't shipped in content of a course, weren't familiar with a technique of online training and studied courses along with their students [9].

According to a research of Analytical center NAFI, 53\% of university teachers considered that the higher education system isn't ready to transfer classes to a remote format.

Taking into account the different content implemented enforcement functions it also became apparent the need for legislative differentiation of powers of the Ministry of education of Russia and Ministry of education and science to establish the order of application of e-learning, distance educational technologies at implementation of educational programs

In this regard, in May 2020, two more draft laws were submitted by the State Duma for consideration: draft Federal law No. 963511-7 "On amendments to article 16 of the Federal law" on education in the Russian Federation "On the issue of voluntary distance learning" [10] and draft Federal law No. 957354-7 "on amendments to article 16 of the Federal law" on education in the Russian Federation " in terms of determining the authority to establish the procedure for using e-learning, distance learning technologies at the implementation of educational programs " [11].

Decrees of the President of the Russian Federation (from 02.04.2020 No. 239, from 28.04.2020 No. 294, from 11.05.2020 No. 316, etc.) establishing measures to ensure the sanitary and epidemiological well-being of the population on the territory of the Russian Federation in connection with the spread of a new coronavirus infection (COVID-19), determine that their provisions, in agreement with the Government of the Russian Federation, can also apply to educational organizations. Although these Decrees of the President of the 
Russian Federation do not fix specific regime rules for the use of e-learning and distance learning technologies as urgent measures for the implementation of educational programs in these conditions.

At the same time, for example, the List of instructions following the meeting on June 10, 2020. "The situation in the education system in terms of the spread of the new coronavirus infection" contains instructions to the Ministry of education and science of Russia to prepare, jointly with the Ministry of education of Russia taking into account experience of realization of educational programs using e-learning and distance education technologies and submit proposals on improving the forms and methods of training and education, educational technology, referring to the prioritizing the implementation of training activities in educational organizations (deadline: November 1, 2020) [12].

At the regional level, the basis for regulating compliance with the anti-epidemic regime in educational organizations was acts of senior officials or the highest executive authorities of the subjects of the Russian Federation, at the local level-acts of local self-government bodies.

The provisions contained in these acts have a recommendatory nature, indicating that the implementation of educational programs using e-learning and distance learning technologies is ensured in accordance with the procedure determined by the administration of the educational organization.

In the structure of the anti-epidemic regime in educational organizations, distance learning forms are objects that carry the regime. Interacting with other carriers of the regime, e-learning and distance education technologies have their own operating environment - an electronic information and educational environment in relation to which, in this case, the legal regime in question is actually established.

As follows from part 3 of the 16th article of Federal law No. 273-FL, the electronic information and educational environment includes: electronic information and educational resources, a set of information technologies, telecommunications technologies, and appropriate technological tools.

It can be noted that according to a study by the Analytical Center NAFI, only $40 \%$ of teachers described the quality of electronic educational materials offered to students for distance learning as "excellent" or "good," $61 \%$ of Russian school teachers rated the technical equipment of their educational organization as "satisfied."

The organization of activities in educational institutes under the anti-epidemic regime has shown that the simultaneous significant increase in the number of users of electronic resources that provide educational content creates technical interruptions and difficulties for users (teachers and students).

According to the analysis of infrastructure availability of educational institutions conducted by the Ministry of education of Russia and the Ministry of communications of Russia, existing conditions allow to ensure the full implementation of educational programs in the distance form, not more than for $25 \%$ of students. In this regard, the Ministry of Education of Russia recommended educational organizations, when implementing educational programs using distance learning technologies, minimize access to electronic and digital educational services and platforms operating on-line [13]. Although there are recommendations to use online resources on publicly available online educational platforms [14].

Taking into account the advisory nature of the provisions stipulated in these acts the main legal means that form the legal regime of distance learning in the context of the coronavirus pandemic are permits and benefits. At the same time, the legal principles and provisions that determine the functional purpose of the regime, due to the lack of established practice, have not been consolidated among the legal means. 


\section{Discussion}

The main aim of any legal regime is the regime rules. However, a special combination of legal tools that create a normative model of behavior and regulate the use of subjective rights, powers, duties and restrictions in the framework of regime regulation of distance learning in the condition of the spread of a new coronavirus infection (COVID-19) is not presented in legal acts.

Thus, the primary acts (letters) of the Ministry of Education of the Russian Federation on strengthening sanitary and epidemiological measures in educational organizations [15] and on organizing distance learning [16] only indicated the need to organize distance learning in accordance with the procedure approved by order No. 816 of the Ministry of education and science of the Russian Federation dated 23.08.2017. At the same time, this procedure establishes rules for the use of e-learning and distance learning technologies by organizations engaged in educational activities when implementing educational programs in their daily activities, that is, in the absence of a threat of an emergency [17].

The temporary procedure for supporting the implementation of educational programs using e-learning and distance learning technologies, approved by the order of the Ministry of education of the Russian Federation dated 17.03.2020 No. 103, also only indicates that organizations engaged in educational activities, when implementing educational programs, use e-learning and distance learning technologies in accordance with the above procedure [18].

The Ministry of education of Russia from 14.03.2020 No. 397 "On the organization of educational activities of organizations implementing educational programs of higher education and appropriate additional professional programs, in terms of preventing the spread of novel coronavirus infection in the Russian Federation" [19] only required when the implementation of educational programs to include the use of various educational technologies to ensure the interaction of students and teaching staff mediated (at a distance), including the use of e-learning and distance learning technologies.

Other acts that establish modal rules of distance learning in terms of preventing the spread of the new coronavirus infection (COVID-19) levels of general and vocational education was the letter of the Ministry of education of Russia, contains information, explanations, recommendations (guidelines) on the peculiarities of organization of educational process in the considered conditions.

The orders of the Ministry of education of the Russian Federation defined only the features of the unified state exam, the state final certification of educational programs of secondary vocational education and admission to training for the new academic year, certification of teachers of organizations engaged in educational activities in order to establish a qualification category in 2020.

At the level of higher education, all regime rules for implementing educational programs using e-learning and distance learning technologies were implemented on the basis of orders of the Ministry of education and science of the Russian Federation.

However, the implemented procedure for fixing and content of regime rules for distance learning in the context of the spread of a new coronavirus infection also does not allow us to speak about the quality and effectiveness of its regime regulation.

The actors involved in the implementation of regime rules of distance learning in terms of the spread of novel coronavirus infection (COVID-19) steel physical and legal persons related to distance learning as the bearer mode and obliged, one to perform these modal rules, others to enforce them.

The subjects who are obliged to comply with the regime rules of distance learning are students, teachers and managers of organizations engaged in educational activities, and the organizations themselves. The Federal law on education, defining their legal status of these 
subjects as participants in relations in the field of education, does not distinguish their legal status as participants in legal regimes. As part of the regime regulation of distance learning in the context of the spread of a new coronavirus infection, these subjects also did not receive additional rights and obligations.

Special entities, ensuring the implementation of the rules of distance learning in terms of the spread of novel coronavirus infection (COVID-19), were: Ministry of education of Russia $[20,21]$ and the Ministry of education and science [21, 22]; their operational headquarters to prevent the spread of novel coronavirus infection; working group of the Ministry for the coordination and support activities associated with the transition to distance learning; bodies of state power of subjects of the Russian Federation exercising the state control in the sphere of education; operators (specialists) of Federal (at the level of ministries) and regional "hotlines" (online services) on the organization of distance learning in the context of the spread of a new coronavirus infection (COVID-19).

All of these special entities has received legal status under the regime of regulation of distance learning in terms of the spread of novel coronavirus infection (COVID-19) and, in fact, formed the administrative subsystem of the system of organizational-legal guarantees of transition of educational institutions on distance learning and work in conditions ensuring compliance with anti-epidemic regime.

At the same time, for example, according to the results of the same study by the Analytical center NAFI, more than a third (35\%) of university teachers (in the school system - every fifth teacher) were not aware of the coordinating activities of state bodies in the field of education to organize the transition to distance learning.

About creation of system of organizational-legal guarantees of transition of educational institutions on distance learning and work in conditions ensuring compliance with antiepidemic regime is the fact that the experts-the operators "a hot line" Ministry of education of Russia for 5 months (from the 18th of March to 13th of August) 2020 spent about 55 thousand consultations for teachers and parents on the organization of distance learning [23]. However, on the other hand, this fact also indicates the quality of regime regulation of distance learning in the context of the spread of a new coronavirus infection (COVID-19). In the applications of citizens received by the Ministry of education and science of Russia in the second quarter of 2020, distance education issues accounted for 4\% (204) of the total number of applications received [24].

The new academic year that has started also has special features in connection with the epidemiological situation of the spread of a new coronavirus infection (COVID-19).

In accordance with the joint letter of Federal Service No. 02/16587-2020-24 and Ministry of education of Russia 1192/03 from 12.08.2020 "On the organization of work of educational institutions" educational institutions in the 2020/2021 academic year must ensure the implementation of educational programs in regular mode and in compliance with sanitary and epidemiological requirements in terms of preventing the spread of the new coronavirus infection (COVID-19). Thus, the organization of the educational process they were instructed to consider the use of distance learning technologies, primarily for carrying out the optional and elective subjects (courses) (with reference to "under the conditions"), to provide learning opportunities on a case of deterioration of the epidemiological situation (without reference to "under the conditions") [25].

The organizations under the Ministry of education and science, the order of the Ministry of 28.08.2020 No. 1133 determined to provide in the 2020/2021 academic year, the implementation of educational programs in full-time education in accordance with the recommendations of the commission on prevention of novel coronavirus infection (COVID19), correspondence classes and evening classes to maximum transfer to remote format. If the epidemiological situation worsens, measures should be taken to implement educational programs using e-learning and distance learning technologies [26]. 


\section{Conclusion}

Thus, experience of the regime of regulation of distance learning in terms of the spread of new coronavirus infection (COVID-19) not only reflects the importance and necessity of legal regulation of relations in the sphere of education with the threat of occurrence and (or) the occurrence of individual emergencies, the introduction of high alert or emergency in the whole territory of the Russian Federation or on the part of, but it provides an opportunity to further improve the legal framework for the use of e-learning and distance learning technologies in the implementation of educational programs, including as measures for the formation of the information space of knowledge.

\section{References}

1. Federal law No. 273-FL On education in the Russian Federation (2012) http://www.pravo.gov.ru

2. V.I. Soldatkin, Cloud of science 2, 214-239 (2018)

3. Federal Institute of education development. Russian Academy of national economy and public administration under the President of the Russian Federation (FIRO RANEPA) (Organization of education in the context of a pandemic. Practice in OECD countries) https://firo.ranepa.ru/novosti/105-monitoring-obrazovaniya-na-karantine/789agranovich-ekspertiza

4. On amendments to articles 71.1 and 108 of the Federal law "On education in the Russian Federation" Federal law (June 8, 2020, No. 164-FL) http://www.pravo.gov.ru

5. On amendments to articles 71.1 and 108 of the Federal law "On education in the Russian Federation" Federal law (June 8, 2020, No. 164-FL) http://www.pravo.gov.ru

6. The Government of the Russian Federation "On measures to protect public health from new coronavirus infection", http://government.ru/news/39218/

7. The education system was not ready to switch to distance learning in the context of the pandemic, https://nafi.ru/analytics/sistema-obrazovaniya-okazalas-ne-gotova-kperekhodu-na-distantsionnoe-obuchenie-v-usloviyakh-pandemi/

8. Official website of the President of the Russian Federation. Meeting on the current situation in the education system. Vladimir Putin held a videoconference meeting on the situation in the education system in the context of the spread of a new coronavirus infection (2020) http://www.kremlin.ru/events/president/news/63376

9. The website "Education" IA "Interfax". Distance learning in extreme conditions (2020) https://academia.interfax.ru/ru/analytics/research/4491/

10. On amendments to article 16 of the Federal law "on education in the Russian Federation" on the issue of voluntary distance learning, https://sozd.duma.gov.ru/bill/963511-7

11. On amendments to article 16 of the Federal law "on education in the Russian Federation" in terms of determining the authority to establish the procedure for using elearning and distance learning technologies in the implementation of educational programs, https://sozd.duma.gov.ru/bill/957354-7

12. List of instructions following the meeting on the situation in the education system in the context of the spread of a new coronavirus infection, http://www.kremlin.ru/acts/assignments/orders/63502

13. On the organization of the educational process letter from the Ministry of education of the Russian Federation (April 8, 2020, no. GD-161/04), http: // base.consultant.ru 
14. Official website of the Ministry of education of the Russian Federation, https://edu.gov.ru/press/2214/ministerstvo-prosvescheniya-rekomenduet-shkolampolzovatsya-onlayn-resursami-dlya-obespecheniya-distancionnogo-obucheniya/

15. On strengthening sanitary and epidemiological measures in educational organizations letter from the Ministry of education of the Russian Federation (March 13, 2020, no. SK-150/03), http: / / base.consultant.ru

16. About the organization of distance learning: letter from the Ministry of education of the Russian Federation (March 17, 2020, no. DT-41/06), http: / / base.consultant.ru

17. Order of the Ministry of education and science of the Russian Federation (August 23, 2017, No. 816) http:// on approval of the Procedure for the use of e-learning and distance learning technologies by organizations engaged in educational activities in the implementation of educational programs base.consultant.ru

18. On approval of the temporary procedure for supporting the implementation of educational programs of primary General, basic General, secondary General education, educational programs of secondary vocational education and additional General education programs using e-learning and distance education technologies order of the Ministry of education of the Russian Federation (March 17, 2020, No. 103) http: / / base.consultant.ru

19. On the organization of educational activities in organizations that implement educational programs of higher education and related additional professional programs in order to prevent the spread of a new coronavirus infection on the territory of the Russian Federation order of the Ministry of science and higher education of the Russian Federation (March 14, 2020, No. 397) http: / / base.consultant.ru

20. On approval of the temporary procedure for supporting the implementation of educational programs of primary General, basic General, secondary General education, educational programs of secondary vocational education and additional General education programs using e-learning and distance education technologies order of the Ministry of education of the Russian Federation (March 17, 2020, No. 103) http: / / base.consultant.ru

21. On urgent measures to prevent the spread of novel coronavirus infection (COVID-19) the order of the Ministry of education of the Russian Federation (March 19, 2020 No. 106) http:// base.consultant.ru

22. On the organization of work in the Ministry of science and higher education of the Russian Federation for the prevention of the spread of a new coronavirus infection in the Russian Federation: the order of the Ministry of education and science of the Russian Federation (14 March 2020 No. 396) http:// base.consultant.ru

23. Official website of the Ministry of education of the Russian Federation, https://edu.gov.ru/press/2793/operatory-goryachey-linii-minprosvescheniya-rossiiprodolzhayut-konsultacii-po-formatu-organizacii-obrazovatelnogo-processa-v-novomuchebnom-godu/

24. Reports on handling requests from citizens and organizations. Information about the results of work with citizens ' appeals in the Ministry of science and higher education of the Russian Federation in the second quarter of 2020, https://minobrnauki.gov.ru/ru/reception/report/

25. On the organization of work of General education organizations letter of the Federal service for supervision of consumer rights protection and human welfare (August 12, 2020, no. 02/16587-2020-24) http:// base.consultant.ru, last accessed 2020/08/21 
26. On organizing the beginning of the 2020/21 academic year in organizations subordinate to the Ministry of science and higher education of the Russian Federation in order to prevent the spread of a new coronavirus infection (COVID-19) on the territory of the Russian Federation order of the Ministry of science and higher education of the Russian Federation (August 28, 2020, No. 1133) http: / / base.consultant.ru 